\title{
Aplikasi Android Kamus Hukum Versi 2.0 Dengan Bantuan Perintah Suara
}

\author{
Nia Ekawati ${ }^{1}$ and Rizki Tri Anugrah Bhakti ${ }^{2}$ \\ Jurusan Teknik Informatika, Fakultas Teknik dan Komputer, Universitas Putera Batam ${ }^{1}$ \\ Jurusan Ilmu Hukum, Fakultas Ilmu Sosial dan Humaniora, Universitas Putera Batam ${ }^{2}$ \\ niaekawati1@gmail.com ${ }^{1}$, rizki.tri.ab@gmail.com ${ }^{2}$
}

\begin{tabular}{l}
\hline \hline Article Info \\
\hline History : \\
Dikirim 10 September 2019 \\
Direvisi 04 Oktober 2019 \\
Diterima 21 Desember 2019 \\
\hline
\end{tabular}

\section{Kata Kunci:}

Aplikasi

Android

Kamus Versi 2.0

Hukum

Perintah Suara

\begin{abstract}
Abstrak
Kamus Hukum menggunakan aplikasi android versi 1.0, merupakan terobosan yang diambil untuk membantu para mahasiswa hukum dan para praktisi dalam memahami secara cepat kamus hukum dengan mudah membuka aplikasi android yang dapat dikatakan sudah banyak digunakan oleh khalayak umum. Versi 1.0 ini masih perlu pengembangan yakni membuat seperti perintah suara, dengan cara menyebut kata yang diminta, maka aplikasi langsung mencari istilah yang dimaksud. Namun pada aplikasi versi 1.0 baru membantu masyarakat umum, belum membantu masyarakat disabilitas. Salah satunya disabilitas pada tunanetra. Kekurangan fisik bagi segelintir orang seperti penyandang tunanetra tentu tidak dapat sepenuhnya menggunakan aplikasi android, perlu bantuan perintah suara agar dapat mencari data yang ada di kamus hukum versi 2.0 yang akan dibangun dari proses pengembangan kamus hukum atau legal dictionary versi 1.0. Versi 1.0 ini masih perlu pengembangan yakni membuat seperti perintah suara, dengan cara menyebut kata yang diminta, maka aplikasi langsung mencari yang dimaksud. Tujuan penelitian saat ini adalah : membantu Masyarakat, mahasiswa dan praktisi hukum yang memiliki keterbatasan/kekurangan fisik penglihatan, dapat menggunakan aplikasi android dengan bantuan perintah suara. Metodologi yang digunakan pada penelitian saat ini adalah: metode pengembangan aplikasi. Hasil dari penelitian diantaranya: Pengujian dilakukan dibeberapa device yang berbeda untuk mengetahui apakah aplikasi dapat berfungsi dengan baik dibeberapa device yang berbeda spesifikasi. Berdasarkan hasil tersebut device dapat menampilkan hasil baik saat kondisi di dalam ruangan tidak banyak noise ataupun kondisi di luar ruangan banyak noise. Maka hasil penelitian kamus hukum versi 2.0 ini dapat digunakan oleh disabilitas pada tunanetra.
\end{abstract}

(c) This work is licensed under a Creative Commons Attribution-ShareAlike 4.0 International License.

\section{Koresponden:}

Nia Ekawati

Program Studi Teknik Informatika, Fakultas Teknik dan Komputer

Universitas Putera Batam

Batam, Indonesia, 29422

Email : niaekawati1@gmail.com 


\section{PENDAHULUAN}

Penerapan teknologi saat ini telah banyak ditemui pada layanan publik atau pendidikan yaitu berupa aplikasi yang membantu pengguna dalam suatu keadaan, sebagai contoh jaman dahulu anak sekolah membawa kamus yang tebal, karena perkembangan teknologi kamus tersebut dapat dibuat praktis dengan kamus digital, anak-anak belajar selalu di ruang kelas namun dengan bantuan teknologi ada permainan online yang bersifat edukasi sehingga anak-anak tidak jenuh dalam belajar, aplikasi pembelian tiket merupakan terobosan baru yang diciptakan untuk mempermudah pengguna dapat memesan tiket dalam waktu cepat serta proses pembayaran fleksibel. Selanjutnya aplikasi pelayanan pemerintah atau BUMN seperti BPJS, PLN, Kepolisian dan Pertamina memberikan layanan secara mobile. Hampir rata-rata aplikasi tersebut dapat diunduh dan diinstal pada perangkat android atau ios oleh pengguna, karena semua tersedia di playstore atau appstore.

Berdasarkan aplikasi yang digunakan oleh pengguna tertentu, masih ada yang luput dari bagian pengguna tersebut, yaitu bagi pengguna yang memiliki keterbatasan/kekurangan fisik. Seperti disabilitas pada tunanetra terkadang menerima perlakuan kurang baik dalam masyarakat umum, atau mahasiwa hukum yang memiliki kekurangan penglihatan ingin menggunakan buku kamus hukum sulit karena memerlukan tulisan khusus untuk dapat dibaca dengan cara diraba tulisan tersebut. Berdasarkan kejadian tersebut peneliti tertarik membantu mahasiswa hukum atau masyarakat umum menggunakan kamus hukum dengan bantuan perintah suara. Hanya dengan menyebut satu kata yang dicari maka kamus hukum dengan perintah suara ini langsung mencari kata yang dicari oleh pengguna, hasil dari pencarian pun berupa suara kembali, mengingat pengguna memiliki keterbatasan penglihatan.

Salah satu bagian tersebut sebelumnya sudah ada yaitu Kamus Hukum Versi 1.0, kamus ini adalah terobosan yang diambil untuk membantu para mahasiswa hukum dan para praktisi dalam memahami secara cepat kamus hukum dengan mudah membuka aplikasi android yang dapat dikatakan sudah banyak digunakan oleh khalayak umum. Versi 1.0 ini masih perlu pengembangan yakni membuat seperti perintah suara, yang dapat membantu mahasiswa atau masyarakat umum yang memiliki keterbatasan/kekurangan fisik penglihatan. Berikut merupakan kamus hukum versi 1.0 yang akan dikembangkan ke versi 2.0.

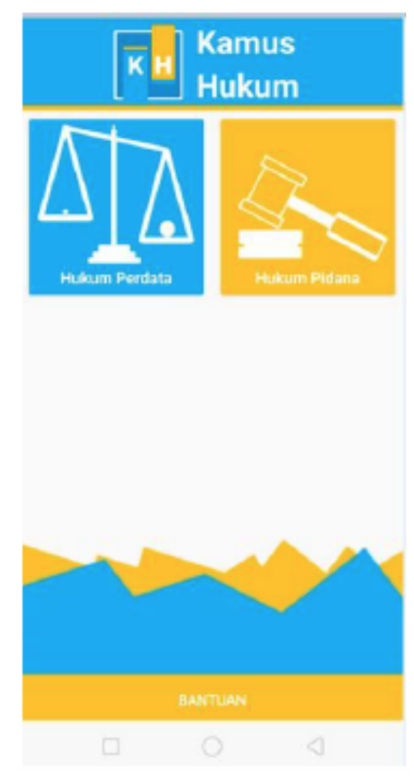

Gambar 1. Kamus Hukum versi 1.0

Kamus versi 1.0 ini sudah dapat diunduh dari playstore, selanjutnya dapat diinstal pada perangkat smartphone/handphone android pengguna. Maka jika pengujian kamus hukum versi 2.0 telah selesai langkah berikutnya akan masuk dalam daftar playstore untuk digunakan oleh mahasiswa hukum dan masyarakat umum yang memiliki keterbatasan/kekurangan fisik penglihatan.

Menurut (Et.co.id, 2016) Berdasar data penjualan global smartphone untuk end-user dari kuartal 12009 s.d kuartal 1 tahun 2016, diperoleh data pada info grafis di bawah ini: 




Gambar 2. Total Jumlah Pengguna Smartphone Seluruh Dunia

Berdasarkan gambar 2, terlihat total jumlah pengguna smartphone seluruh Dunia meningkat, ini menandakan bahwa sistem operasi yang digunakan pada smartphone mudah digunakan oleh pengguna akhir (enduser). Sistem operasi tersebut adalah sistem operasi android. Tahun 2010 pada kuartal pertama, 8,36 juta smartphone terjual dari merk Apple dengan iOS mereka. Kekurangan fisik bagi segelintir orang seperti penyandang tunanetra tentu tidak dapat sepenuhnya menggunakan aplikasi android, perlu bantuan perintah suara agar dapat mencari data yang dimaksud. Aplikasi ini akan dibangun pada kamus hukum versi 2.0 yang merupakan hasil pengembangan dari kamus hukum versi 1.0. Hal ini dapat dirujuk pada penelitian [1] Seorang tunanetra mempunyai keterbatasan untuk melihat, salah satu bagiannya adalah proses bangun, mereka membutuhkan indra peraba sebagai pendukung proses tersebut, apalagi jika tunanetra itu sejak lahir sudah dialaminya. Hasil penelitian kedua subjek menyampaikan definisi, karakteristik serta jenis segitiga berdasarkan refleksi pemahaman dari mereka pada pengalaman yang telah didapat. Penelitian lain mengungkapkan [2] Proses kegiatan seni tari dan bahasa merupakan satu-satunya media yang dipakai untuk penyampaian materi gerak. Seperti tarian pada anak tunanetra, hal ini akan menjadi unik, menarik sekaligus sulit. Berdasarkan proses tersebut maka lahirlah bahasa-bahasa baru untuk anak tunanetra yang dapat digunakan pada proses penyampaian komunikasi dalam proses kegiatan latihan seni tari anak tunanetra. Ada penelitian menurut [3] Pentingnya dalam mengerjakan pendidikan inklusif dengan baik. Penelitian dibuat untuk memberikan informasi dalam implementasi kegiatan pendidikan inklusif dan aksesibilitas siswa dengan low version. Atau lain halnya pada penelitian [4] Bentuk keberagaman kaum tunanetra disebabkan oleh beberapa aspek dan dimensi beragam yakni pengetahuan agama, penghayatan, akhlak, pengalaman ibadah, dan kepercayaan. Bentuk kaum tunanetra mempunyai pengaruh yang signifikasi terhadap perkembangan psikologis dan sosialnya.

Menurut [5] diperoleh fakta: Kamus hukum dapat dikatakan memiliki istilah yang terkadang kurang dipahami oleh masyarakat umum. Sehingga jika masyarakat mendengarkan istilah-istilah hukum di berbagai media akan berusaha mencari apa makna istilah hukum tersebut. Atau masyarakat akan membuka berupa buku kamus hukum yang dimilikinya, tapi jika tidak memiliki buku tersebut hanya dapat mencari melalui pencarian google. Buku kamus hukum yang cukup tebal tentu memerlukan waktu cukup lama, namun jika ada sebuah aplikasi yang membantu seperti kamus digital, tentu masyarakat atau user dapat dengan cepat menemukan makna dari istilah hukum tersebut. Maka terciptalah kamus digital dengan nama legal dictionary. Berdasarkan penelitian [6] diperoleh fakta: Android adalah sistem operasi yang sedang diminati karena bersifat open souce. Penelitian ini membahas mengenai banyak buku kumpulan doa islami yang beredar dipasaran karena tebal buku dari kumpulan doa membuat menyulitkan karena harus dibawa kemana-mana. Hasil penelitian tersebut dengan Aplikasi Kumpulan Doa maka orang akan mudah membacanya dimana saja, tanpa kebingungan harus selalu membawa buku. Lain hal lagi dengan penelitian menurut [7] mereka mengemukakan bahwa Perusahan "X" merupakan perusahaan yang bergerak dalam bidang jasa telekomunikasi seluler di Indonesia, layanan yang dimiliki adalah Call dan SMS (Short Message Service). Sistem otomatis dapat mencatat pada database transaksi baik Call dan SMS. Namun Call dan SMS ini belum dapat memberikan informasi transaksi secara cepat dan mudah, terlebih dapat menampilkan grafik. Hasil pengujian memperlihatkan bahwa aplikasi menggunakan aplikasi bergerak berbasis Android dapat memberikan informasi mengenai jumlah transaksi Call dan SMS dalam bentuk grafik melalui perangkat bergerak berbasis Android. Selain itu jika membahas mengenai Androif, 
sistem ini dapat diaplikasikan ke proses akademik yang dikemukakan oleh [8] Karena ada Batasan dalam mengakses akademik online pada Universitas Tama Jagakarsa yakni hanya dapat mengakses melalui mozilla, maka peneliti menciptakan suatu aplikasi yang dapat meningkatkan efektivitas mengunakan akademik dalam bentuk aplikasi akdemik online menggunakan Bahasa pemrograman java yakni aplikasi android. Ada juga yang mengemukakan aplikasi mobile [9] Proses kelola dan organisasi tugas akhir dengan baik dapat memudahkan semua bagian terkait untuk proses kegiatan. Namun terkadang proses administrasi umum seperti informasiinformasi yang dibutuhkan pada tugas akhir harus dilakukan dengan proses manual. Hasil penelitian dengan sistem berbasis mobile menggunakan android, mahasiswa dapat lakukan proses administrasi kapan dan dimana saja.

Merujuk pada penelitian [5], maka penelitian ini kedepan akan membangun legal dictionary aplikasi android versi 2.0. Membantu bagi masyarakat, mahasiswa hukum dan praktisi yang memiliki kekurangan fisik. Berdasarkan uraian sebelumnya, maka judul pada penelitian ini adalah "Aplikasi Android Kamus Hukum Versi 2.0 Dengan Bantuan Perintah Suara". Berdasarkan latar belakang diatas, maka batasan masalah dalam penelitian ini adalah sebagai berikut: untuk membantu masyarakat, mahasiswa hukum atau praktisi yang memiliki kekurangan fisik, membahas kamus hukum, membahas pembuatan aplikasi android, tools menggunakan android studio, dan alat perekam suara. Rumusan masalah dalam penelitian ini adalah sebagai berikut: bagaimana membuat aplikasi android kamus hukum versi 2.0 dengan bantuan perintah suara? Tujuan penelitian saat ini adalah: membantu masyarakat, mahasiswa dan praktisi hukum yang memiliki keterbatasan/kekurangan fisik penglihatan, dapat menggunakan aplikasi android dengan bantuan perintah suara.

\section{METODE PENELITIAN}

\subsection{Pengumpulan Data}

Pengumpulan data yang dilakukan pada penelitian ini, dibagi menjadi tiga tahap adalah sebagai berikut:

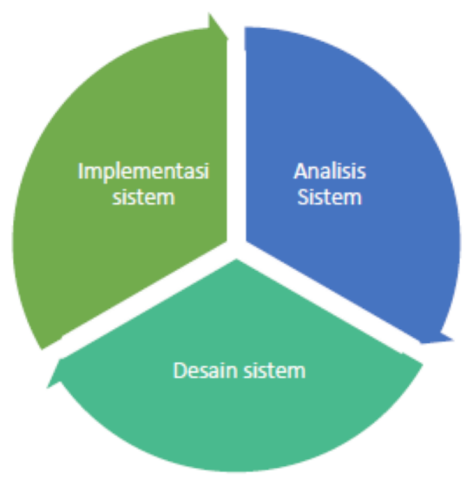

Gambar 3. Pengumpulan Data

Proses pertama adalah analisis sistem, pada aplikasi versi 1.0 masih menggunakan papan ketik untuk mencari kata istilah hukum yang akan dicari. Pengembangan yang akan dibuat pada versi 2.0 tidak menggunakan papan ketik melainkan langsung perintah suara. Proses kedua adalah desain sistem, pada aplikasi versi 1.0 memiliki dua pilihan yaitu kamus hukum perdata dan hukum pidana. Pengembangan yang akan dibuat pada versi 2.0 karena tidak menggunakan papan ketik proses langsung perintah suara ini dikhususkan untuk penyandang disabilitas tunanetra, tampilannya langsung gambar microphone untuk memberikan perintah suara. Proses ketiga adalah implementasi sistem, pada aplikasi versi 1.0 pengguna dapat langsung menerima informasi dari istilah yang dicari. Pengembangan pada versi 2.0 karena membantu untuk disabilitas tunanetra, maka informasi yang keluar berupa suara dengan penjelasan dari istilah yang dicari. 


\subsection{Konsep Teori}

\subsubsection{Software Development}

Saat proses pengembangan aplikasi dari kamus hukum versi 1.0 ke versi 2.0 banyak proses yang berubah, walaupun kegunaan aplikasi ini sama yaitu memproses pencarian kata dari istilah hukum, berikut gambar yang dapat dijelaskan beberapa tahap.

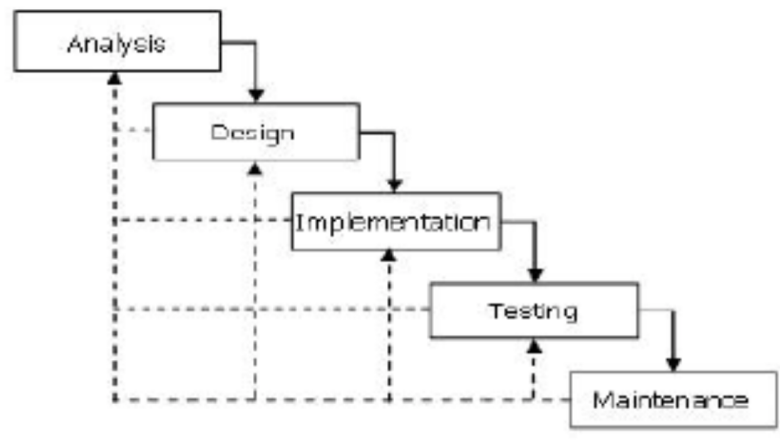

Gambar 4. Metode Waterfall

\subsubsection{Analysis}

Menurut [10] Analysis yaitu tahap mengenali masalah yang ada muncul pada pengguna. Masalah yang muncul dari kamus hukum versi 1.0 yaitu pengguna yang memiliki keterbatasan/kekurangan fisik penglihatan, karena kamus hukum versi 1.0 diinput dengan cara mengetik kata dari istilah yang akan dicari. Bagi sebagian pengguna yang memiliki keterbasan/kekurangan fisik penglihatan tentu tidak dapat melakukan proses input tersebut. Sehingga dalam pengembangan aplikasi kamus hukum versi 2.0 proses input dirubah dengan bantuan perintah suara dari pengguna. Kelebihan dari aplikasi kamus hukum versi 2.0 adalah tidak perlu mengetik istilah, cukup dengan perintah suara dari pengguna aplikasi ini akan mencari apa yang diminta pengguna.

\subsubsection{Design}

Penjelasan menurut [10] Design adalah rancangan sistem yang akan dibuat baik flowchart atau tampilan interface. Berikut pengembangan yang terjadi pada kamus hukum digital tersebut pada gambar 5 .

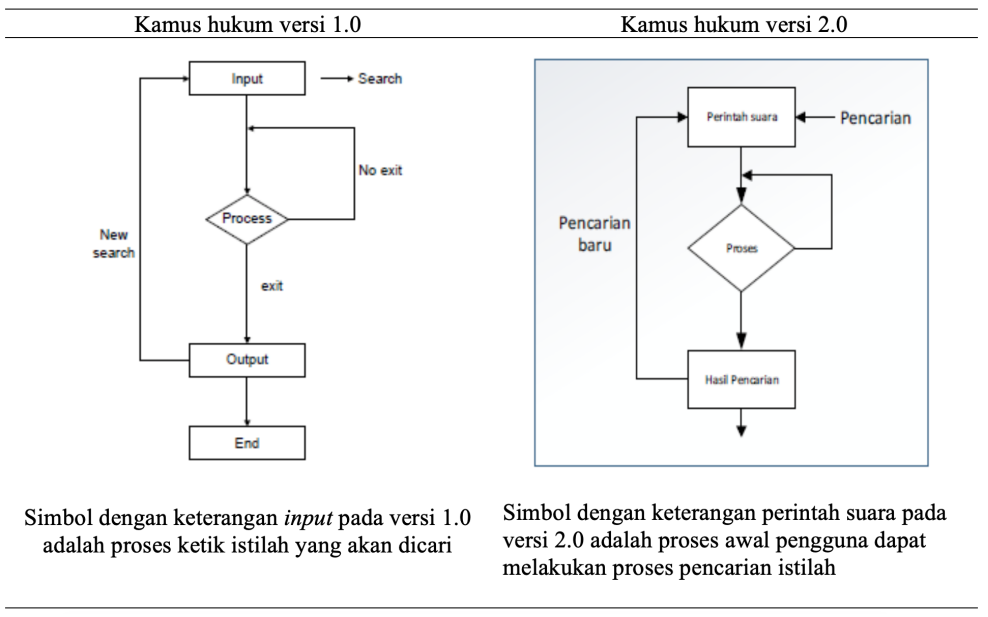

Gambar 5. Penjelasan Flowchart 
Maka didapat sebuah solusi bagi pengguna aplikasi yang memiliki keterbatasan/kekurangan fisik penglihatan dapat tertolong dengan proses input menggunakan perintah suara.

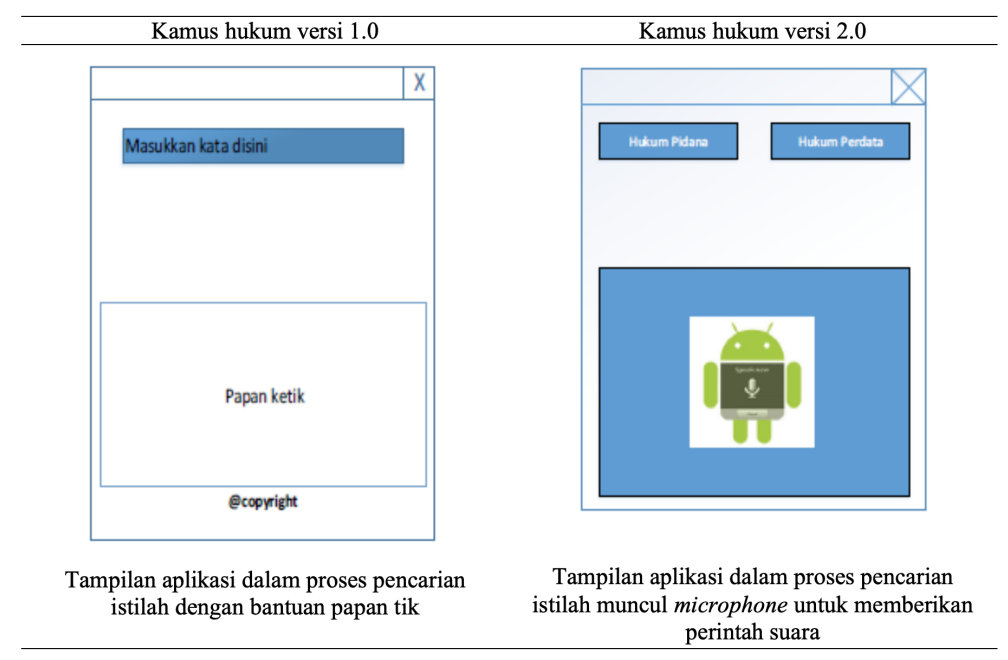

Gambar 6. Penjelasan Interface

Selain flowchart yang telah dijelaskan sebelumnya, gambar 6 menjelaskan tampilan yang berbeda dari kedua aplikasi, terlihat kamus hukum versi 2.0 memudahkan pengguna yang memiliki keterbatasan/kekurangan fisik penglihatan karena dirancang muncul microphone untuk memberikan perintah suara.

\subsubsection{Implementation}

Pendapat [10] Implementation merupakan tahap selanjutnya setelah design. Berikut penjelasan mengenai kamus digital tersebut.



Gambar 7. Penjelasan Implementation

Terlihat pada gambar 7 perbedaan dari implementasi pada aplikasi tersebut. Pengembangan dari aplikasi kamus versi 1.0 adalah adanya bantuan microphone untuk memberikan perintah suara, sehingga memudahkan pengguna yang memiliki keterbatasan/kekurangan fisik penglihatan. 


\subsubsection{Testing}

Pengembangan yang belum terlaksana pada kamus hukum versi 2.0 adalah dapat diunduh pada playstore. Sedangkan kamus hukum versi 1.0 sudah masuk dalam list di playstore (Gambar 11).

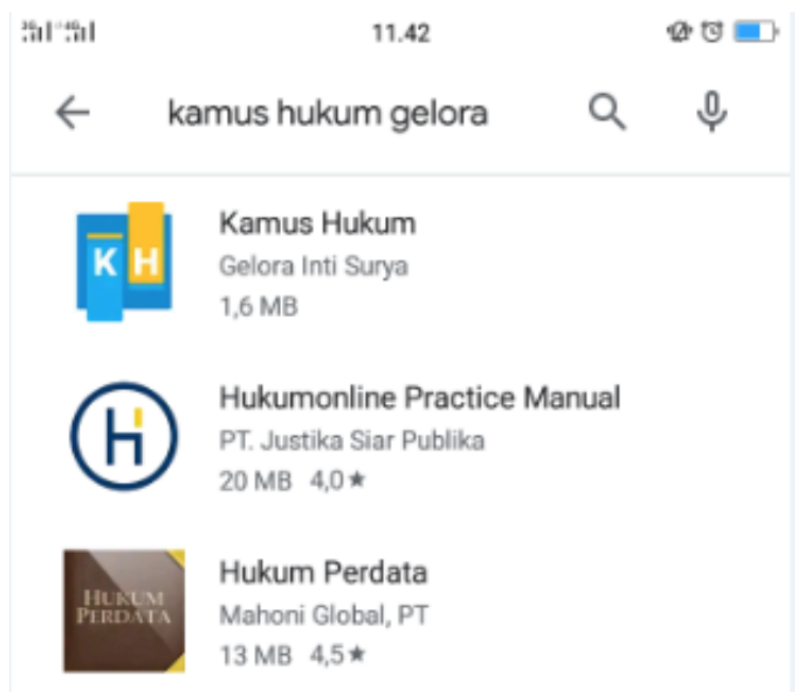

Gambar 8. Kamus Hukum Versi 1.0 Berada di Playstore

Sedangkan kamus hukum versi 2.0 masih dalam proses uji coba belum masuk pada playstore, hasil testing pengujian aplikasi dapat dilihat pada section 3 . Berikut spesifikasi yang digunakan pada saat testing:

1. Sistem Operasi: Android

2. Sistem Operasi Android Minimum: Android 5.0 (Lollipop)

3. Size Aplikasi: $5 \mathrm{MB}$

4. Ram Minimum: $1 \mathrm{~GB}$

5. Ram Rekomendasi: $2 \mathrm{~GB}$

6. Proseccor Minimum: Snapdragon octa-core 651

7. Support Speech Input/Speech Recognition

\subsubsection{Maintenance}

Penjelasan [10] Maintenance adalah pemeriksaan bagian dari aplikasi supaya tetap berjalan dengan semestinya. Kamus hukum versi 1.0 sampai saat ini masih dimaintenance dalam sisi database maupun perpanjangan hosting. Maka kedepan apabila apliaksi kamus hukum versi 2.0 sudah selesai dalam proses pengujian, langkah berikutnya akan masuk dalam playstore dan akan mengalami maintenance apabila ada penambahan data di database maupun perpanjangan hosting.

\section{HASIL DAN PEMBAHASAN}

Kamus Tunanetra adalah kamus hukum versi 2.0 berbasis android yang menggunakan pengendali suara untuk melakukan pencarian arti pada kamus. Kamus tunanetra ini dibuat untuk membantu para tunanetra untuk mencari arti pada kamus dengan sekali sentuh dan ucap. Sangat user friendly bagi para penyandang tunanetra. Hasil pada penelitian ini adalah sebagai berikut:

1. Instal File Apk

Instal aplikasi android kamus tunanetra menggunakan aplikasi bereksistensi .apk. Setelah mengklik aplikasi .apk kamus tunanetra. Akan langsung dialihkan ke proses instalasi aplikasi android. Sentuh Instal maka aplikasi akan langsung menginstal. 


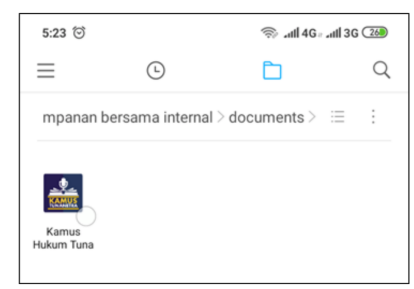

Gambar 9. Proses instal .apk

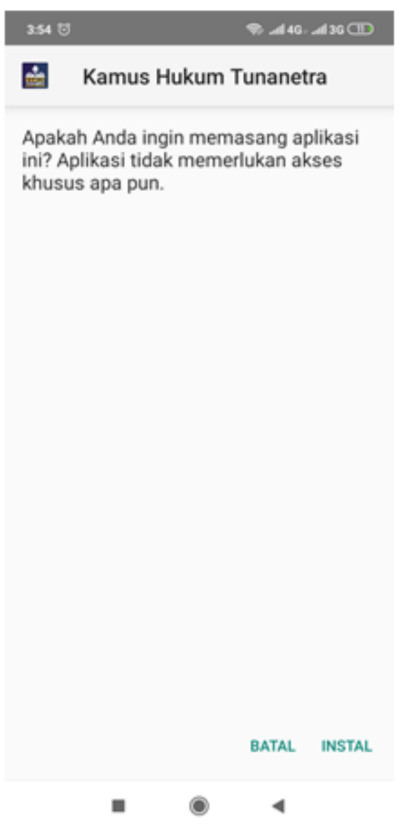

Gambar 10. Pertanyaan Pada Saat Proses Instal

Berikut tampilan aplikasi setelah proses instal apk

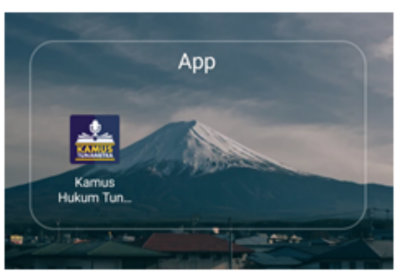

Gambar 11. Kamus Tunanetra Sudah Terinstal

2. Splash Screen Berikut tampilan splash screen aplikasi android kamus tunanetra. Ketika pertama kali menjalankan aplikasi pengguna akan disambut dengan splash screen seperti gambar disamping.

\section{Main Menu}

Tampilan aplikasi kamus tunanetra seperti gambar berikut. Pada tampilan utama aplikasi terdapat tombol Microphone. Tombol tersebut berfungsi untuk melakukan pencarian. Ketika disentuh maka aplikasi akan langsung melakukan fungsi speech recognition dan mendeteksi suara, menjadikan teks, dan melakukan pencarian pada database. 


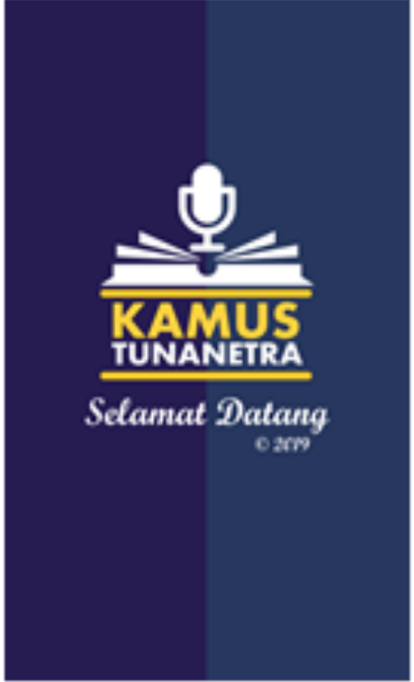

(a)
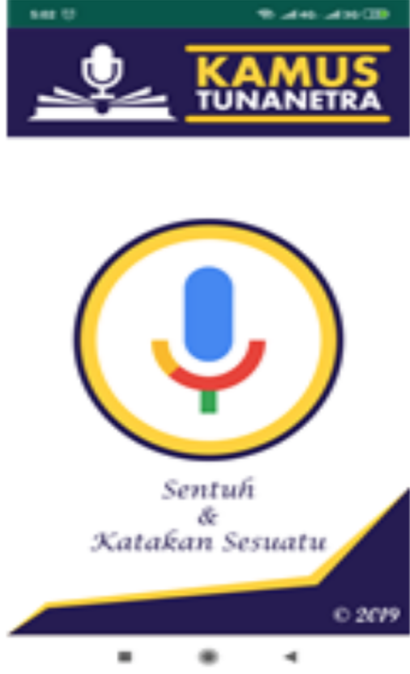

(b)

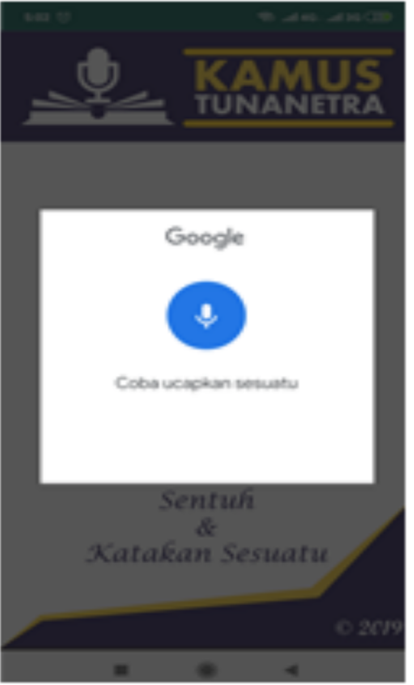

(c)

Gambar 12. (a) Tampilan Splash Screen, (b) Tampilan Main Menu, (c) Tampilan Muncul Mic Untuk Memberikan Perintah Suara

Ketika menyentuh tombol mic aplikasi langsung medeteksi suara dan meterjemahkan kedalam teks dan melakukan pencarian.

\section{Tampilan Hasil Pencarian}

Setelah melakukan deteksi pada suara dan melakukan pencarian aplikasi akan langsung menampilkan hasil dan akan membacakan teks hasil pencarian. Pada tampilan ini terdapat dua tombol

(a) Tombol mic: digunakan untuk melakukan pencarian lainnya

(b) Tombol replay: digunakan untuk mengulang suara untuk membacakan hasil pencarian

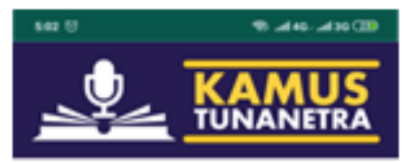

\section{Hukum Acara Perdata}

Hukum acara yang melaksanakan dan mempertahankan hukum perdata materiel; hukum perdata formal

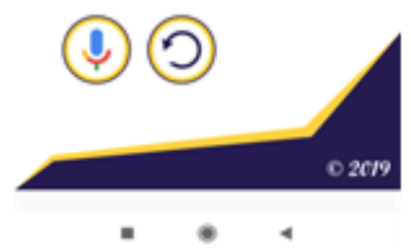

Gambar 13. Tampilan Hasil Pencarian 


\section{Tampilan Pencarian Lainnya}

Ketika tombol mic pada tampilan hasil pencarian disentuh maka aplikasi akan memulai untuk melakukan pendeteksian suara dan mencari hasil lainnya.

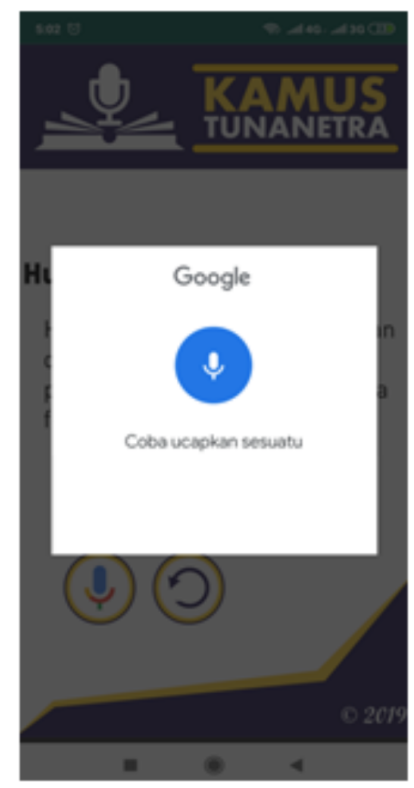

Gambar 14. Tampilan Untuk Memulai Pencarian Lain

Pada saat aplikasi telah selesai diinstal, maka langkah selanjutnya masuk proses pengujian. Pengujian dilakukan dibeberapa device yang berbeda untuk mengetahui apakah aplikasi dapat berfungsi dengan baik dibeberapa device yang berbeda spesifikasi. Daftar spesifikasi device yang digunakan untuk pengujian dapat dilihat pada tabel:

Tabel 1. Spesifikasi Device

\begin{tabular}{|c|c|c|c|}
\hline \multirow{2}{*}{ Nama Device } & \multicolumn{3}{|c|}{ Spesifikasi } \\
\cline { 2 - 4 } & Versi Android & Ram & Processor \\
\hline Device 1 & Android 5.1.1 & 3 GB & QualcommMSM8939EightCore \\
\hline Device 2 & Android 8.1.0 & $6 \mathrm{~GB}$ & Eight Core \\
\hline Device 3 & Android 8.1.0 & 2 GB & QualcommSDM450EightCore \\
\hline Device 4 & Android 6.0 & 4 GB & EightCore \\
\hline Device 5 & Android 9 & 3 GB & Octa-core Max 1.80 GHz \\
\hline
\end{tabular}

Hasil ujicoba pada 5 (lima) device dengan spesifikasi yang berbeda adalah sebagai berikut:

Tabel 2. Hasil Pengujian Pada 5 (Lima) Device

\begin{tabular}{|l|l|l|l|l|l|}
\hline \multirow{2}{*}{ Pengujian } & \multicolumn{5}{|c|}{ Hasil Pengujian } \\
\cline { 2 - 5 } & Device 1 & Device 2 & Device 3 & Device 4 & Device 5 \\
\hline Instal APK & Berjalan dengan baik & Berjalan dengan baik & Berjalan dengan baik & Berjalan dengan baik & Berjalan dengan baik \\
\hline Menjalankan Aplikasi & Berjalan dengan baik & Berjalan dengan baik & Berjalan dengan baik & Berjalan dengan baik & Berjalan dengan baik \\
\hline Masuk Splash Screen & Berjalan dengan baik & Berjalan dengan baik & Berjalan dengan baik & Berjalan dengan baik & Berjalan dengan baik \\
\hline Masuk Menu Utama & Berjalan dengan baik & Berjalan dengan baik & Berjalan dengan baik & Berjalan dengan baik & Berjalan dengan baik \\
\hline Menekan Tombol Mic & Lebih Lambat Bereaksi & Berjalan dengan baik & Berjalan dengan baik & Berjalan dengan baik & Berjalan dengan baik \\
\hline Menampilakan Hasil & Lebih Lambat Bereaksi & Berjalan dengan baik & Berjalan dengan baik & Berjalan dengan baik & Berjalan dengan baik \\
\hline Tombol Replay & Berjalan dengan baik & Berjalan dengan baik & Berjalan dengan baik & Berjalan dengan baik & Berjalan dengan baik \\
\hline
\end{tabular}


Pengujian selanjutnya dilakukan pengujian terhadap berapa jarak ideal sumber suara perintah ke microphone device android agara dapat menjalankan perintah. Pengujian dilakukan dengan berbagai jarak, didalam ruangan atau tidak banyak noise, dan kondisi luar ruangan yang banyak noise. Hasil pengujian dapat dilihat pada tabel berikut:

Tabel 3. Hasil Pengujian Berdasakan Jarak Dan Kondisi

\begin{tabular}{|l|l|l|}
\hline Jarak & Kondisi dalam ruangan tertutup (Tidak Banyak Noise) & Kondisi luar ruangan (Banyak Noise) \\
\hline $1 \mathrm{CM}$ & Dapat Menampilkan Hasil & Dapat Menampilkan Hasil \\
\hline $4 \mathrm{CM}$ & Dapat Menampilkan Hasil & Dapat Menampilkan Hasil \\
\hline $6 \mathrm{CM}$ & Dapat Menampilkan Hasil & Dapat Menampilkan Hasil \\
\hline $10 \mathrm{CM}$ & Dapat Menampilkan Hasil & Lambat Merespon Tetapi Hasil Pencarian Benar \\
\hline $15 \mathrm{CM}$ & Dapat Menampilkan Hasil & Speech Input tidak mengerti apa yang diucapkan \\
\hline $30 \mathrm{CM}$ & Dapat Menampilkan Hasil & Speech Input tidak mengerti apa yang diucapkan \\
\hline $60 \mathrm{CM}$ & Spech Input Salah Mengartikan Kata-kata & Speech Input tidak mengerti apa yang diucapkan \\
\hline $65 \mathrm{CM}$ & Speech Input tidak mengerti apa yang diucapkan & Speech Input tidak mengerti apa yang diucapkan \\
\hline
\end{tabular}

Berdasarkan penjelasan dari hasil penelitian dan pengujian diatas, maka dapat dibandingkan dari kamus hukum versi 1.0 diantaranya:

1. Proses pencarian pada kamus hukum versi 1.0 dibantu oleh papan tik untuk mengetik istilah yang akan dicari dan langsung ditemukan penjelasan istilah tersebut, sedangkan kamus hukum versi 2.0 harus melakukan pengujian jarak karena yang diinput ke dalam aplikasi adalah perintah suara.

2. Pada kamus hukum versi 1.0 pencarian istilah dibagi menjadi dua bagian hukum perdata dan hukum pidana, namun pada versi 2.0 dijadikan satu dalam proses menggunakan microphone untuk memberikan perintah suara.

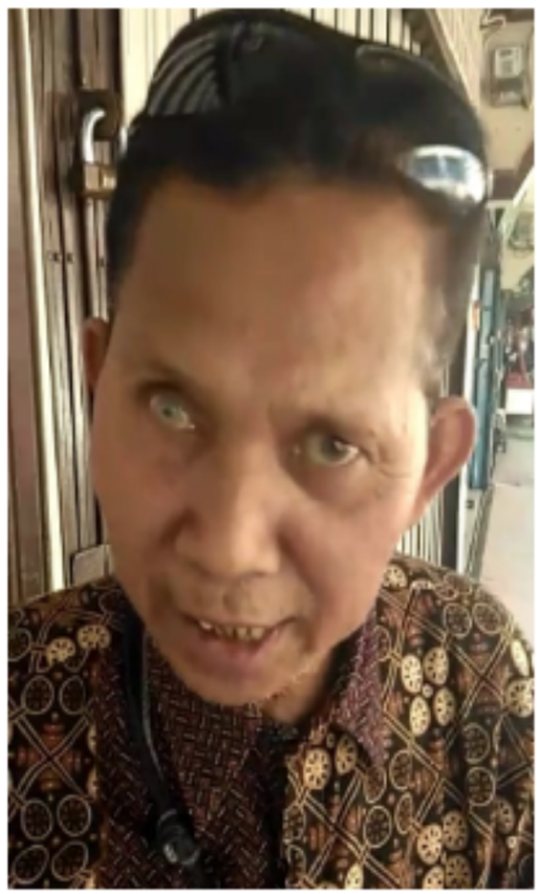

(a)

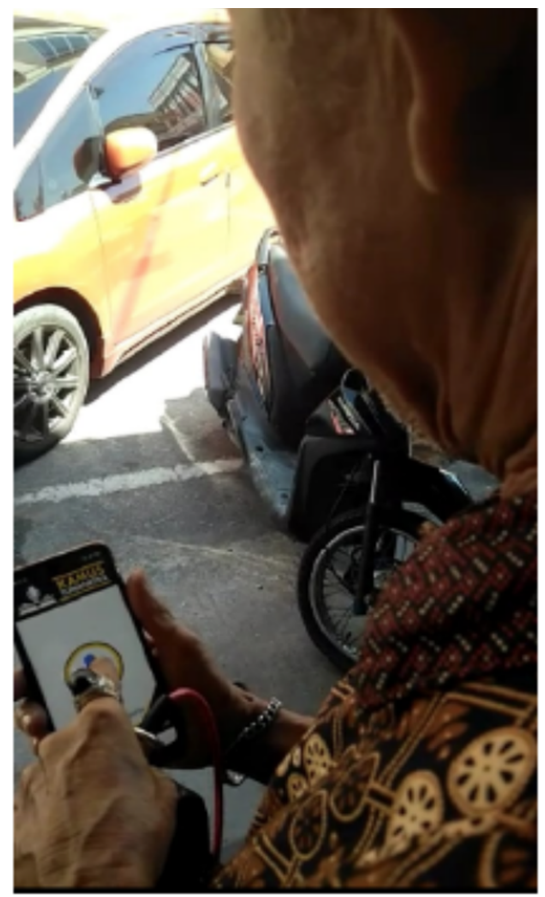

(b)

Gambar 15. (a) Bapak M. Said, (b) Contoh Pemakaian Sistem 
Pembahasan pada penelitian ini, mencoba di-implementasikan kepada pengguna untuk membantu pengguna yang memiliki keterbatasan/kekurangan fisik penglihatan seperti pada pengguna bernama Bapak M. Said.

Bapak M. Said adalah seorang tunanetra yang kesehariannya mencari nafkah dengan cara nyanyi keliling. Pada saat aplikasi kamus hukum versi 2.0 di implementasikan, penerimaan dari Bapak Said kamus hukum versi 2.0 ini dapat membantu bagi tunanetra seperti beliau, semoga dapat berguna untuk mahasiswa, pelajar dan masyarakat umum yang tidak memiliki keterbatasan seperti beliau, ucap Pak Said. Maka dapat diartikan aplikasi android kamus hukum versi 2.0 ini memiliki kelebihan dalam proses pencarian secara perintah suara tanpa harus mengetik pada papan ketik, selain itu hasil yang didapat pada proses pencarian adalah penjelasan dari istilah dengan luaran berupa suara. Sehingga bagi segelintir orang dengan fisik yang kurang salah satu adalah tunanetra, membantu bagi mereka karena cara kerja dari sistem android ini mudah digunakan.

\section{KESIMPULAN}

Kesimpulan pada penelitian ini adalah Aplikasi yang digunakan dapat membantu kepada masyarakat ataupun mahasiswa yang memiliki kekurangan dalam hal ini adalah disabilitas tunanetra. Proses pencarian pada kamus hukum versi 1.0 dibantu oleh papan tik untuk mengetik istilah yang akan dicari dan langsung ditemukan penjelasan istilah tersebut, sedangkan kamus hukum versi 2.0 harus melakukan pengujian jarak karena yang diinput ke dalam aplikasi adalah perintah suara. Pada kamus hukum versi 1.0 pencarian istilah dibagi menjadi dua bagian hukum perdata dan hukum pidana, namun pada versi 2.0 dijadikan satu dalam proses menggunakan microphone untuk memberikan perintah suara.

\section{UCAPAN TERIMA KASIH}

Penulis mengucapkan terima kasih kepada Direktorat Riset dan Pengabdian Masyarakat (DRPM) yang telah memberi dukungan financial terhadap penelitian ini.

\section{DAFTAR PUSTAKA}

[1] R. Muthmainnah, "Pemahaman siswa tunanetra (buta total sejak lahir dan sejak waktu tertentu) terhadap bangun datar segitiga," J. Pendidik. Mat. Mat, vol. 1, no. 1, pp. 15-27,.

[2] S. Muharomah, "Penggunaan bahasa pada anak tunanetra: (pengamatan terhadap anak tunanetra melalui proses penalaran dalam kegiatan tari di panti sosial bina netra cahaya bathin," DEIKSIS, vol. 8, no. 2, pp. 135-146,

[3] E. Rahayu, M. Riri, and E. Irda, "Penyelenggaraan pendidikan inklusif bagi anak tunanetra low vision (deskriptif kualitatif di sman 3 padang," JUPPEKhu, vol. 3, no. 3, pp. 1-15,.

[4] Sulthon, "Pola keberagamaan kaum tuna netra dan dampak psikologis terhadap penerimaan diri," $Q U A L$ ITY, vol. 4, no. 1, pp. 45-68,.

[5] R. Ekawati and B. Nia, "Legal dictionary menggunakan aplikasi android," IT J. Res. Dev, vol. 3, no. 1, pp. 85-93,.

[6] E. Maiyana, "Pemanfaatan android dalam perancangan aplikasi kumpulan doa," J. SAINS DAN Inform. Res. Sci. Inform, vol. 4, no. 11, pp. 54-67,.

[7] U. Hastomo and Y. Fanji, "Perancangan dan pembuatan perangkat lunak aplikasi android untuk pengolahan data transaksi pada perusahaan telekomunikasi 'x' dengan menggunakan pentaho," J. Tek. POMITS, vol. 2, no. 1, pp. 77-82,.

[8] S. Andriyani, "Aplikasi akademik online berbasis mobile android pada universitas tama jagakarsa," $J$. Sains dan Teknol. Utama, vol. XI, no. 1, pp. 15-26,.

[9] M. SIMATUPANG and M. Julianto, "Sistem aplikasi pengelolaan tugas akhir berbasis mobile," IT J. Res. Dev, vol. 3, no. 2, pp. 66-75,

[10] A. Nugroho, Rekayasa Perangkat Lunak. Yogyakarta: Andi Offset. 


\section{BIOGRAFI PENULIS}

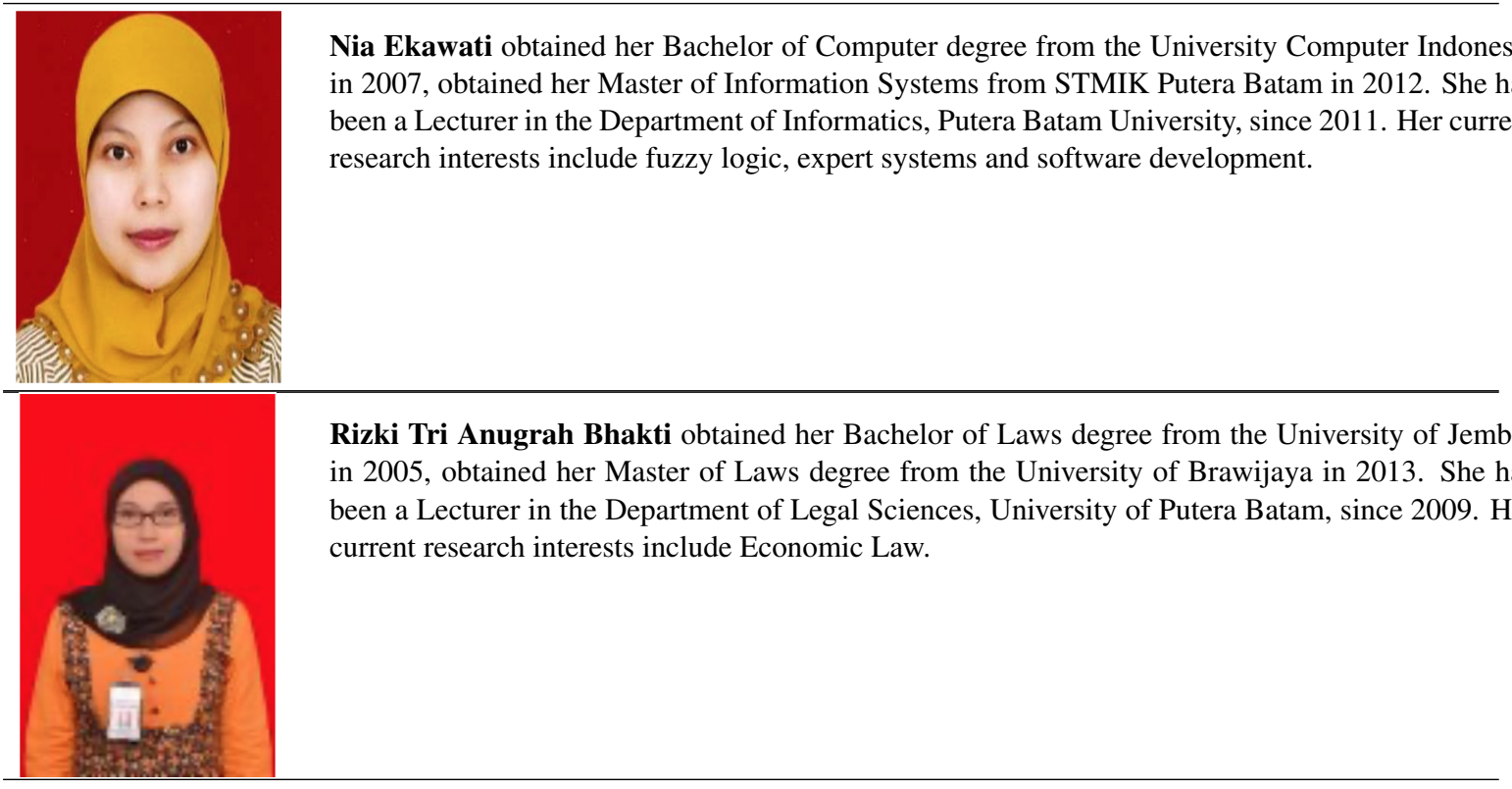

